This is a pre-print of an article published in Competitiveness Review. The final authenticated version is available online at: https://doi.org/10.1108/CR-01-2020-0013

Berbegal-Mirabent, J.; Gil-Doménech, D.; de la Torre, E.M. (2021). Examining the strategies behind universities' technology transfer portfolio: How different patterns of resource consumption can lead to similar technology transfer outputs profiles. Competitiveness Review, 31(3): 571-593. DOI: 10.1108/CR-01-2020-0013.

\title{
Examining the strategies behind universities' technology transfer portfolio: How different patterns of resource consumption can lead to similar technology transfer profiles
}

\begin{abstract}
Purpose - This research analyses how different patterns of production factors consumption of Spanish universities lead to specific technology transfer (TT) profiles (outcomes).

Design/methodology/approach - Adopting a resource-based view perspective (RBV), qualitative comparative analysis (QCA) is used to analyse the relationship between different combinations of resources - human resources, financial resources and support services - and various portfolios of TT outcomes - intellectual or industrial property agreements, spin-offs and TT income.

Findings - Results indicate that there is no unique formula of resource consumption that leads to a specific portfolio of TT outcomes. These results seem to reflect the characteristics and competences added by universities, along with the characteristics of their socioeconomic context. From a RVB perspective, this indicates that the considered resources are substitutable.

Practical implications - The effectiveness of university policies is expected to vary by university, e.g. depending on the type of resources that is most relevant in the university's production process. To develop competitive advantages Spanish public universities must resort to internal intangible resources or specific and inimitable combinations of the available resources.
\end{abstract}

Social implications - Since Spanish universities are heterogeneous and display different TT portfolios they address the needs of different users.

Originality/value - Previous studies have failed to acknowledge the heterogeneity among universities. To perform our analysis we employed QCA, an innovative methodology in the higher education sector that enables us to purposefully acknowledge institutional diversity (in both resources and results). This allows us to indirectly take into account the capabilities of universities using a more holistic approach to evaluate their competitiveness. 
Keywords: technology transfer; universities; heterogeneity; patterns; profiles; qualitative comparative analysis.

\section{Introduction}

Knowledge and technology are central to growth and economic development. In an era where organisations are called upon to foster creativity and innovation, the establishment of R\&D alliances between science-based institutions and firms is intended to speed up technological innovation and reduce time lag between discoveries and their industrial application (Maietta, 2015; Lazzarotti et al., 2016) for the benefit of society at large.

In this context, universities are expected to play a paramount role by meeting training needs - through teaching activities - establishing the basis for science and technology - through research functions - and contributing to the economic and social development of their territories (Gunasekara, 2006). Said differently, the socioeconomic role of the contemporary university is nowadays broader than it was three decades ago: universities do not only have to provide highly qualified graduates and researchers and produce cutting-edge knowledge, but they also have to offer innovative solutions through knowledge and technology transfer (TT) mechanisms. In this sense, universities have embraced economic and social development as a third mission carried out through TT and commercialisation (Etzkowitz, 1998) — but also through outreach activities and lifelong learning programs (E3M, 2012).

To successfully develop this third mission, universities must abandon the "ivory tower" configuration (Etzkowitz et al., 2000) and foster links with society at large, but more specifically with the (local) productive fabric (Uyarra, 2010; Grimpe and Hussinger, 2013) and government. In this way, the so-called "entrepreneurial universities" (Etzkowitz, 2004) become part of a "triple helix" (university, industry and 
government - see Etzkowitz and Leydesdorff, 2000), where they acquire an active role in fostering innovation, competitiveness and economic and social progress (Etzkowitz and Leydesdorff, 2000; Secundo et al., 2016).

These entrepreneurial universities, together with government and industry, aim at facilitating the generation and exploitation of technology and knowledge-while fulfilling their other two missions: teaching and research (Etzkowitz, 2004; Guerrero and Urbano, 2012). Within this context, academics, instead of only focusing on what D’Este and Perkmann (2011) call "blue-skies research", are responsible to connect in an entrepreneurial way the worlds of science and technology. By acting like this, they increase their socio-economic impact and translate their research results into marketable outcomes (Casani et al., 2014) that can be transferred to and used by industry and governments.

To keep up with these demands and provide good value for money to society, universities have enlarged their service portfolios and adapted their traditional structures (Stensaker and Benner, 2013). Collaborations with businesses, local and regional public authorities, and other local actors are the traditional practices to achieve this purposesee Perkmann et al. (2013) for an extensive review. However, universities face important constraints in terms of resources, which impede them from successfully engaging in different forms of TT activities while maintaining high levels in teaching and research duties (Berbegal-Mirabent et al., 2013).

The current setting is that universities struggle in an increasingly competitive environment where they are constantly asked to excel in all three university missions simultaneously: this model is known as the one-size-fits-all university (SánchezBarrioluengo, 2014). Additionally, universities do not only have to compete in multiple tasks simultaneously, but they also have to do so with scarce resources. Consequently, 
to increase their efficiency and effectiveness, universities behave strategically, trying to make the most of their resources by focusing on those activities in which they advance their competitors (Antonelli, 2008). According to de la Torre et al. (2019), since different activities address the needs of specific stakeholders, universities display heterogeneous activity profiles and stakeholder orientations very much influenced by their resources and structural characteristics (path dependency) but also by their territory (especially their economic characteristics — see Stonkiene et al. 2016), strategic planning and intangible assets (such as the university reputation-see Maduro et al., 2018). This entails that socio-economic benefits arising from university-industry interactions significantly differ within countries and from one university to another. In this context, examining how universities are using their resources in order to pursue different TT activities becomes an interesting topic that deserves further investigation (Cesaroni and Piccaluga, 2016).

In so doing, the literature has failed so far to acknowledge universities' capacity to leverage competitive advantages from their unique combination of resources (as a result of their heterogeneity). Drawing on the resource-based view (RBV) literature (Wernerfelt, 1984; Powers, 2004), we investigate university patterns of resource consumption in TT activities, but unlike previous studies, we purposefully take into account that universities may produce different mixes of TT outputs. Specifically, we analyse how different factors-labour and capital resources as well as support services - are combined to explain universities' TT outcome profiles. The underlying assumption behind this approach is that, given the specific features and the strategic (or path dependent) orientation of a university, the TT portfolio might differ in breadth (variety of outcomes) and in depth (number of outcomes of the same type). To the best 
of the authors' knowledge, this approach better mirrors the real configuration of the HE systems, constituting a novelty in the literature.

RBV has been extensively applied to analyse firm performance but has hardly been used in HE contexts (Bobe and Kober, 2015—-see Powers and McDougall, 2005; Larty et al., 2017 for the case of university TT activities). In our case, it serves us to pursue, in a novel way, the main objective of this study: to investigate university patterns of resource consumption in TT activities and their relation to different $\mathrm{TT}$ portfolios (understood as different combinations of TT outputs). Accordingly, building upon the literature on the RBV perspective, in this study we propose a novel framework that enables the identification of unique combinations of internal and external resources that explain the TT performance of institutions.

The method that suits better this research objective is qualitative comparative analysis (QCA). This method assumes complex causality and focuses on asymmetric relationships that detect configurations that are minimally necessary and/or sufficient for obtaining a specific outcome (Meyer et al., 1993). In this way, QCA allows for considering institutional heterogeneity: not all universities should allocate their efforts towards producing the same type of TT outcomes - given that resources are scarce and universities address their objective functions differently. Additionally, with QCA it is possible to consider that outcomes are explained by a mixture of several conditions, and that it is possible to produce (or reach) a specific outcome by means of different resource consumption patterns (Woodside, 2016) - it does not calculate the isolated effect of the selected variables on the outcome, but their combination.

Note that we do not formulate any specific requirement on how factors should be combined to achieve a particular TT profile. There is not a correct or wrong way of combining these elements, it depends on the characteristics, the resources, the 
environment and the strategy the university decides to follow in order to build its competitive advantage(s). QCA serves well to this purpose. Recent works further confirm the suitability of this methodology to study TT and innovation processes (Álvarez-Coque et al., 2017; Berbegal-Mirabent et al., 2015), although its use in the higher education (HE) context is still incipient.

This study contributes to the existing literature on TT activities in HEIs in three main ways. First, our research approach goes beyond traditional linear associations, acknowledging the TT process is a complex one (Castillo et al., 2018), and thus, requires the exploration of asymmetrical relationships between factors. Second, because universities are heterogeneous and follow different strategies (Abankina et al., 2016; Agasisti and Johnes, 2015; Berbegal-Mirabent et al., 2019) causal complexity and equifinality are assumed — that is, different paths might conduce to similar results. Third, to the best of the authors' knowledge, this study is one of the first to examine how different TT outcomes can be obtained simultaneously. That is, besides the use of a more traditional approach in which universities should produce all the TT outcomes considered (i.e., number of intellectual or industrial property agreements, TT income, and spin-offs) a fourth outcome is considered as an "OR" combination using Boolean algebra. With this later outcome we allow universities to freely "choose" which type(s) of TT outcome(s) to produce. By waving this restriction - all universities should equally value and produce the same outcomes-it is possible to correctly account for the complexity of universities' technology transfer portfolios (Lafuente and BerbegalMirabent, 2019).

Our empirical application also adds new insights to the regional development literature and the role played by universities. We consider data on the Spanish public HE system for 2016. The Spanish HE system is one of the largest in the European 
Union, representing more than 10 per cent of all HE students in Europe (European Tertiary Education Register, data for the academic year 2017-18) and it has a sole type of $\mathrm{HE}$ institution: universities. It is a decentralised system and regional governments are responsible for policies on education, under the coordination of central government. However, Spanish public universities are usually regarded as homogeneous: the only sources of heterogeneity usually recognised are the institutional size and the subject mix (technical universities) — de la Torre et al., 2018. This study poses that even in low differentiated HE systems there is heterogeneity in the type of TT outcomes produced and the combination of resources used to deliver them.

The remainder of the article is as follows. Next section sets the theoretical underpinnings and supports the selection of the factors considered to drive TT outcomes. We next describe the sample and the methodology. Afterwards, we present the results. Lastly, we elaborate on the discussion of the results and outline the practical implications.

\section{Theoretical underpinnings}

\section{Dealing with heterogeneity in higher education studies}

The HE landscape is highly heterogeneous (Abankina et al., 2016). In other words, not all universities address their objective function in the same way (Berbegal-Mirabent et al., 2013). Differences in a number of factors such as size, territorial scope, legal status, academic level, subject mix, or the entrepreneurial approach shape how universities define their activity mix, and therefore, determine their performance (Niederl et al., 2014). While some universities might display a balanced orientation among teaching, research and socio-economic engagement duties, others might adopt a specific-mission focus, showing different mission mixes. Also, territorial ambitions and interests may 
shape the final form of the institutionalisation of universities activities, including knowledge transfer activities (e.g. Kitawa, 2010; Sá et al., 2013; Hladchenko and Pinheiro, 2019).

One of the main problems arising from heterogeneity is the absence of a consensus when trying to define a framework to characterise universities. Undoubtedly, such a scheme would be useful not only for comparative studies but also for policy making and (summative and formative) evaluation purposes. From the review of the literature, two main strategies are envisioned when trying to deal with the noise introduced by such heterogeneity: (1) establishing a specific criterion and classifying universities accordingly, the so-called prescriptive classifications, or (2) grouping universities based on a set of parameters through multivariate analysis, known as descriptive classifications — see de la Torre et al. (2018).

In the first case, universities are discretionarily grouped based on specific characteristics, usually their age, legal status, history, or year of foundation. Universities can also be classified according to their orientation or by degree of specialisation as in Johnes (2006). Yet, other studies prefer using a pre-existing typology, such as the taxonomy established by the Carnegie Foundation in the USA (McCormick and Zhao 2005), or elaborate a new classification as it is done in the works of Howells et al. (2008) and Bartelse and van Vught (2007) — this later study sponsored by the European Commission in an attempt to develop a pan-European typology.

The second approach consists of applying multivariate techniques (usually cluster analysis) to empirically group universities based on a set of parameters deemed relevant by the researcher. The studies using this approach either aim at identifying typologies of universities as an ultimate goal (e.g. Howells et al., 2008; Bonaccorsi and Daraio, 2009; Daraio et al., 2011) or at trying to understand the role of heterogeneity in 
an empirical analysis (e.g. Johnes and Johnes 2009; Boliver, 2015; Agasisti et al., 2016; de la Torre et al., 2017a; Berbegal-Mirabent et al., 2019).

This study is inserted in this latter trend of the literature. Because the aim is to acknowledge the diversity among universities to better understand the TT outputs production process, this study abandons the system perspective (macro level) and instead, focuses on the individual institutional approach of each university (micro level). In so doing, we go a step further and suggest a novel approach that allows for identifying the patterns followed by universities when conducting their activities, and more specifically, when engaging in TT activities. The ultimate goal is not that much to identify different levels of commitment to TT activities, but to discover the different recipes (or configurations) universities follow to accomplish university-industry endeavours, getting a detailed picture of their various approaches to TT activities and not an overall diagnostic.

\section{Application of the Resource-Based View to assess Technology Transfer activities} at universities

RBV considers that the capabilities ${ }^{1}$ of institutions represent the internal strengths or weaknesses that determine their performance (e.g. Barney, 1991; Penrose, 1959; Prahalad and Hamel, 1990; Selznick, 1957; Wernerfelt, 1984). Accordingly, RBV can be seen as a framework to study idiosyncratic resources (Rumelt, 1997). This approach considers institutions as "bundles of heterogeneous resources" and is based on the idea that the level of success that institutions achieve depends on the access to unique resources or their combinations (Larty et al., 2017, p. 995). Thus, RBV can be used as a

\footnotetext{
${ }^{1}$ For a synthetic summary of the attributes that a specific resource must meet in order to provide an institution with a strength in the form of competitive advantage over their competitors, see Bobe and Kober (2015).
} 
framework that will assist us in the identification of unique resource combinations that explain the success of institutions (in our case, TT activities).

Although the RBV has been widely applied to investigate firm performance, there has been a dearth of literature using RBV to empirically assess how HEIs perform (Bobe and Kober, 2015). Only a few examples are found. For instance, Larty et al. (2017) apply qualitative analysis techniques to investigate how the networking capabilities of intermediaries (i.e. universities in the UK) shape the creation and expansion of a regional network for knowledge exchange. Bobe and Kober (2015) also use the RBV to determine how competitive resources of Australian university schools/departments generate organisational capabilities, and consequently give them sustainable competitive advantage. Perhaps the work of Powers and McDougall (2005) is the one closer to ours. These authors use the RBV to investigate the effects of different resources on the success of two specific TT programmes-university start-up formation and technology licensing with firms-in the United States. Through regression techniques they identify human capital, financial resources, and other organisational resources as significant predictors of the studied outcomes.

According to O'Shea et al. (2008), there are different factors that might shape TT performance of HEIs. Although these authors primarily focus on spin-offs, their classification may be extrapolated to other TT outputs. These factors include: individual features, organisational universities' attributes (e.g., human capital, commercial resources and institutional activities), institutional and cultural factors (i.e., the social context), and external elements (e.g., regional infrastructures). Among them, the second category-organisational factors - includes items that depend in a more intrinsically way on universities, and therefore in which we can better spot the impact of differences in resource management behaviour. For the purpose of this study we adopt a RBV 
perspective (Wernerfelt, 1984; Powers, 2004) and focus on the resources-or organisational factors as labelled by O'Shea et al. (2008) —in which universities base their TT activities.

More specifically, our study particularise for the case of Spanish public universities proving on-campus (graduate and postgraduate) education. As earlier explained, Spanish public universities are heterogeneous at the micro level, but they have little flexibility to build a competitive advantage based on their resources because of the strong control and monitoring of public activities, budget and finances (de la Torre et al., 2017b).

However, RBV studies have demonstrated for other types of institutions that competitive advantages also emerge from the links among resources and their complementarity (Christmann, 2000; Ensign, 2004; Foss et al., 2008; Gibbert, 2006; Lampel and Shamsie, 2003; Molloy et al., 2011; Newbert, 2007, 2008; Rouse and Daellenbach, 2002) thanks to synergistic effects (Amit and Schoemaker, 1993; Molloy et al., 2011). In this sense, the way in which an institution bundles its resources is an additional source of heterogeneity (Molloy et al., 2011), providing Spanish public universities with some room to take specific managerial decisions: even universities with similar resources may combine them in different ways. Different decisions in this respective could entail that universities with the best resources may not outperform their peers in TT activities (see for example Molloy et al., 2011 for the case of firms): the different combinations of resources are more determinant of an institution's performance than any single resource on its own (Kraaijenbrink et al., 2010; Newbert, 2007, 2008).

Following Powers and McDougall (2005), we apply RBV considering human resources (Feng et al., 2012), financial resources (Berbegal-Mirabent et al., 2012) and 
other organisational resources such as support services (Autio et al., 2004) as the three main dimensions or types of resources that are key in TT processes. In the next subsection we provide a detailed description for each of these actors.

Given our interest in the identification of patterns of resource consumption in TT activities and their relation to different TT portfolios-understood as different combinations TT outcomes-we use a novel methodology (QCA) that facilitates this type of analysis. As such, a distinguishing feature of our analysis is that, unlike previous studies, we consider that not all HEIs have to follow the same pattern and produce the same outcomes. Hence, we take into account a variety of TT outputs - intellectual or industrial property agreements, university spin-offs and TT income-and all the possible combinations among them. By adopting this methodological approach we are able to provide an answer to the following unresolved questions: In which way(s) universities combine their resources for TT purposes? Is there any relation between these strategic patterns (i.e., combination of resources) and the configuration of the TT portfolio? To the best of our knowledge, there is no previous research that has attempted to address these questions.

In the next section we elaborate on each one of the aforementioned dimensions (i.e., factors or resources) that are key in TT processes.

\section{A framework for resource consumption in Technology Transfer activities}

As argued above, we consider three dimensions as key (factors or resources) in TT processes. Starting with the first dimension, human resources capture both individuals' capabilities and prior experience. As knowledge and skills cannot be taken away from the individual, this type of capital is unique, becoming particularly relevant in knowledge intensive organisations in the service sector, such as it is the case of $\mathrm{HE}$ 
institutions (De la Torre et al., 2016). Thus, academic and TT support staff working at universities constitutes a valuable asset, acting as the university's scientific source of expertise. The academic staff is in charge of developing new cutting-edge scientific advancements (Powers and McDougall, 2005). Typically, they have the technical knowledge but lack the know-how and the managerial skills required to start-up a new venture, fill in a patent or establish a university-industry collaboration agreement (Powers and McDougall, 2005). Human capital working at TTOs is expected to facilitate and speed up such administrative processes, playing a key role in TT processes (Caldera and Debande, 2010; Cartaxo and Godinho, 2017). The more stablished the TTO is, the more effectively will facilitate technology transfer-TTOs have a steep learning curve (Thursby and Thursby, 2002; Powers and McDougall, 2005). Accordingly, for the purpose of this study human capital refers not only to the academic staff involved in TT transfer activities, but also to the non-academic staff responsible for offering support to this kind of activities (Feng et al., 2012).

Concerning the second dimension, previous works have found that access to financial resources is positively related with the development of TT activities (De Coster and Butler, 2005; Muscio, 2010). As Guerrero and Urbano (2012) state, financial resources allow overcoming the barriers of universities to satisfy social demands. Following prior studies (e.g. Berbegal-Mirabent et al., 2012) this study stresses the effect of a TTO's annual budget on TT outcomes. Knowledge creation and diffusion tend to require huge investments (Landry et al., 2007); therefore, universities with larger TTO's budgets will be more prone of getting involved in TT activities-either in breadth (different types of outcomes) or in depth (number of outcomes of the same type). 
The third dimension corresponds to support services. The strong market imperfections in technology commercialisation make this activity particularly challenging (Callon and Muniesa, 2005) along with the identification of technology commercialisation opportunities (Arora et al., 2001). These arguments apply to any type of organisation commercialising technology, including universities and TTOs. In such context, TTOs can develop their TT duties either using their own resources or by hiring external support services. Outsourcing specific tasks, such as commercialisation or invention disclosure evaluation may help TTOs with small budgets or workforce to overcome their lack of resources and/or know-how (see Autio et al., 2004, for the case of firms). However, to the authors' knowledge, the outsourcing activity of TTOs has not been widely studied yet, and most studies focus in the effects for firms (e.g. Lichtenthaler and Ernst, 2012; Parker and Hine, 2014). We address this limitation by including support services (outsourcing) in the analysis measured as the presence (or absence) of external support for both the invention disclosure evaluations and the commercialisation process.

\section{Data and method}

\section{Data}

Following the theoretical framework, the empirical model can be formulated as expressed in equation (1):

$$
\mathrm{TT}=\mathrm{f} \text { (human resources, financial resources, support services) }
$$

where $T T$ denotes a TT outcome. Four different outcomes are employed, and consequently, four models will be run. The TT outcomes are the following: (i) the number of intellectual or industrial property (IIP) agreements, gathering non-disclosure agreements concerning IIP, accounting for the ability of the university to conduct 
cutting-edge research with industrial applications - these include licences on national patents, confidentiality agreements to protect know-how, material transfer agreements, agreements on utility models and on biological materials, plant varieties and microorganisms registered, and agreements on digital content (i.e. computer programs, databases and web pages) that have been recorded in some way (including internal records) and registered trademarks; (ii) the number of university spin-offs established in the last five years, as the entrepreneurial route to commercialise research results; (iii) TT income, denoting how active the university is in establishing meaningful interactions with firms in terms of demand for the knowledge produced in universities and its socio-economic value and commercial success-it includes the income from R\&D and consultancy contracts, minor technical services provided, IIP and companysponsored professorships ${ }^{2}$; and (iv) an outcome as an "OR" combination of the previous three - the rationale behind this outcome is that the model allows universities to choose which outcomes to produce, given their own characteristics, i.e. our empirical approach takes into account that not all HEIs have to follow the same pattern and produce the same outcomes.

As stated in equation (1), resources - acting as antecedent conditions using the QCA nomenclature-refer to the dimensions outlined in the previous section. Specifically, human resources are operationalised through the number of full-time equivalent academic staff and the technical staff working at TTO. Financial resources are proxied by the TTO's budget. Lastly, external support for the invention disclosure evaluations and for the commercialisation are used to indicate the presence of support services (outsourcing), which are expected to strengthen ties with the business sector.

\footnotetext{
${ }^{2}$ For a comprehensive explanation of the advantages and caveats of these three indicators, see de la Torre et al. (2017a).
} 
Descriptive statistics for the variables of interest-outcome and antecedent conditions_-are presented in Table 1.

\author{
Insert Table 1 about here
}

The empirical setting considers the Spanish public HE system. Given the fundamental role that universities play in regional development through knowledge production and regional knowledge exchange (Harrison and Turok, 2017; Larty et al., 2017), the regional focus of the present paper is expected not to limit but to clearly enrich the debate on the impact of universities to regional development (e.g. Cabanelas et al., 2017; Pugh, 2017; Vallance, 2016).

Data come from the CRUE (Conference of Rectors of Spanish Universities) and the RedOTRI (Network of Spanish Technology Transfer Offices) reports, and include information for the Spanish HE system providing on-campus undergraduate and postgraduate education. Following previous literature, we consider a lag of two years between resources and outcomes (Berbegal-Mirabent et al., 2013). An initial dataset comprising all 47 Spanish public universities that offer in-person education was built, yet, due to some missing values in the variables of interest, the sample was reduced to 40 universities.

\title{
Method: qualitative comparative analysis
}

Qualitative comparative analysis (QCA) is used as the methodological technique, which allows for considering institutional heterogeneity among universities. Specifically, our propositions are that: (i) not all universities should allocate their efforts towards producing the same type of TT outcomes (TT profiles); and (ii) universities can reach a 
specific outcome through different resource consumption patterns. This approach is useful for identifying the composition of universities' TT portfolio and whether this composition is linked to some strategic patterns (i.e., combination of resources).

Given that we expect to identify different paths of resource consumption leading to equally valid destinations (i.e., TT profiles), we do not impose any restriction or a priori proposition on how factors should be combined. On the contrary, our models allow universities to "freely" decide how to manage (i.e., combine) their resources.

QCA assumes complex causality and focuses on asymmetric relationships that detect configurations that are minimally necessary and/or sufficient for obtaining a specific outcome (Ragin, 2013; Rihoux and Ragin, 2009). Thus, compared to traditional regression models, the results obtained do not express the net effects of the conditions but different configurations causing the outcome of interest (Vis, 2012) - it does not calculate the isolated effect of the selected resources on the outcome, but their combination. Feasible recipes are not just combinations of antecedent conditions or resources (either positive or negative) but also of their absence (Wu et al., 2014).

Another feature that makes QCA particularly attractive for this study is that despite performing well in medium and large samples, previous studies have also shown the validity of this approach in datasets with few observations (Fiss, 2011).

The first step in QCA requires transforming the variables - the outcome and the antecedents conditions-into fuzzy sets, in a scale from 0 (denoting full nonmembership) to 1 (full membership). This process, known as calibration, demands an in-depth knowledge on the topic - both on theory and on the cases under analysis - in order to establish appropriate breakpoints (Ragin, 2008): 0.95 for full membership, 0.05 for full non-membership and 0.5 for the cross-over point or point of maximum ambiguity. This process is reported in Table 2. For dichotomous factors, crisp-set 
transformation is preferred (Ragin, 2008). Compared to crisp-sets, fuzzy-sets are not only binary but also metric at the same time. This way it is possible to distinguish between cases that are 'more in' (closer to full membership) a set than others.

QCA is appropriate for evaluating sufficiency and necessary conditions. A condition $X$ is considered to be necessary to produce the outcome $Y$ if this condition appears in all instances of $Y$. A condition is sufficient if it always leads to the outcome. In other words, a sufficient condition would be a subset of the outcome. Yet, $X$ may not be enough by itself: a single condition is rarely sufficient or necessary, and thus, feasible recipes tend to include combinations of conditions (Ragin, 2008). Before proceeding with the analysis, we tested if any of the antecedent conditions in our models were necessary. As none of the variables displayed consistency values higher than 0.9 (Schneider and Wagemann, 2012), we concluded that there is no antecedent factor considered to be a necessary condition to cause the outcome.

\section{Insert Table 2 about here}

Next, the truth table is built, a matrix with $2^{k}$ rows-being $k$ the number of conditions (resources) - that contains all logically possible combinations of conditions. Each column represents a condition, and each row contains the empirical cases (Fiss, 2011). For the purpose of this study four different models are run, one for each TT output (agreements on IIP, spin-offs, TT income and their "OR" combination). Cases are assigned to the combinations in which their membership scores are greater than 0.5 . Using Boolean algebra minimisation, a logical reduction of statements is generated. Two parameters are considered: coverage - the empirical relevance of a solution — and consistency - quantifies the extent to which cases sharing similar conditions lead to the 
same outcome. In this study we used the fsQCA software (version 2.0). Results are shown in Table 3.

\section{Empirical results}

Following Ragin and Fiss (2008) we report the results of the intermediate solution (see Table 3). As for the notation, black circles ("•") indicate the presence of a condition, white circles (“O”) denote its absence, and blank cells represent ambiguous conditions.

Different configurations explain the TT outcomes under analysis, all of them exhibiting acceptable consistency indices $(\geq 0.80)$. Results from the models in which outcomes are assessed in an individual fashion (agreements on IIP, spin-offs, R\&D income) suggest that there is no a 'magic recipe', but instead, there are different patterns - combinations of inputs - that universities follow, confirming our initial intuition that Spanish universities are heterogeneous and address their objective function differently. This finding can be interpreted as evidence that the considered resources are substitutable; that is, individual factors per se do not constitute a competitive advantage. On the contrary, the competitive advantage relies on how these factors are combined.

Broadly speaking, and from a vertical reading of the tables, it can be inferred that human resources are a valuable attribute, both when operationalised in terms of academic staff and TTO staff. While the formers apply their knowledge to produce cutting-edge discoveries that are sound to the industry, TTO staff is in charge of supporting the commercialisation process and bring their expertise in establishing university-business collaborations. In those cases where TTO staff is scarce (configurations S_3, S_4, RD_4 and TT_5, Table 3), this absence can be compensated 
with TTO large budgets, which allow asking for external help in this process $\left(\mathrm{S} \_3\right)$, or with commercialisation support services (S_4, RD_4 and TT_5).

\section{Insert Table 3 about here}

Financial resources are also found to be an antecedent of TT outcomes. Specifically, they are a key ingredient for IIP agreements when support services are not provided (IIP_3 and IIP_5). In the case of R\&D income, the TTO budget is also found to be relevant (RD_3 and RD_6). In order to establish university-industry partnerships - which might lead into R\&D contracts with firms-universities have to compete in a globalised market where other corporations can act as R\&D providers. Therefore, investments are needed in order to raise external awareness of the research conducted at universities. When the target output is spin-offs, financial support tends to come from business angels and other external agents. Yet, there are still few universities managing large amounts of seed capital. As shown in S_3 a large TTO budget is paramount when the other antecedents are missing. Also, financial resources are useful for spin-offs (S_6) when both staff and commercialisation services are present, but there is no additional external support for invention disclosure evaluations.

As for the influence of external support services, results reveal that, contrary to our initial intuition, they are not that crucial for all TT portfolios. In particular, they are not essential when the output considered is IIP agreements. Contrarily, our empirical analysis shows that support services are helpful when it comes to explain R\&D contracts income (this antecedent appears in five out of six configurations). As for the creation of new spin-offs, commercialisation support services are more important than those oriented towards the evaluation of the new technology. 
Turning into the specificity of the results of the last model (the one in which universities can freely choose which TT outcomes to produce), several conclusions can be drawn. There is no antecedent condition that exerts a consistent effect in the different configurations outlined-i.e. all factors can lead to the outcome either when being present or absent (it depends with whom they are combined). Additionally, there are some interesting common patterns that deserve further attention. First, commercialisation services are found to have a positive effect on TT, as they are present in half of the recipes obtained (TT_3, TT_5 and TT_6). A critical mass of human capital (TT_2) or a large TTO budget (TT_4) can help overcome the absence of such services. The only configuration that includes all support services-for both the invention disclosure evaluations and commercialisation-(TT_6) shows that combining this services with TTO staff (although not having academic staff) can lead to fruitful results in terms of TT. Specifically, two universities located in the north of Spain-UNICAN and UDCfall into this category (see Table 4 for the detailed results and Appendix 1 for the coding of the names of the universities).

Insert Table 4 about here

Another key finding is the role of the TTO budget. Results reveal that a shortage in financial resources is not an impediment for transferring technology if there is a skilled pool of researchers and external commercialisation services available (TT_5). However, it is important noting that moderate budgets can also yield in TT outcomes when other resources are scarce (TT_4). A closer look into this configuration reveals two different patterns in terms of the composition of the TT portfolio. For instance, URV and UMH seem to have decided to direct all efforts to one specific outcome (IIP 
and spin-offs, respectively); contrarily, URJ and UJI seem to have a quite opposite strategy, that is, prioritising diversification rather than concentration. Yet, this strategy seems not to be effective, as low-moderate outcomes are obtained.

An alternative route that conduces to TT outcomes is shown in TT_3, which results from combining large budgets, TTO staff and external commercialisation services. This is the case of UC3M, UNIZAR, UPV, USC and EHU. Following Ragin's (2008) recommendation, the two causal paths with greater raw coverage (configurations TT_1 and TT_2) deserve further attention. Both TT_1 and TT_2 are very different. From the first one (TT_1) it can be inferred that, universities lacking resources (absence of TTO staff, financial resources and evaluation support) have a route that allows them accomplish with the third mission. Additional descriptives indicate that there are three universities (USAL, UVIGO and UCO) falling into this category, that in terms of TT, their resources are quite limited; notwithstanding, they are doing an efficient use of them. Yet, not all three follow the same strategy in terms of the composition of their TT portfolio. While UVIGO excels at all outcomes and have quite a balanced portfolio in all dimensions, USAL seems to concentrate their resources in the production of IIP and spin-offs, whereas UCO does so in the latter category (spin-offs). Other universities that are well explained by this recipe are those characterised by a broad academic diversity and responding to regional needs (UNIOVI, ULL and UIB). However, the results indicate that these universities should benchmark the previous three, as the outcomes they are obtaining are rather low. One plausible explanation for these results is that the characteristics of the territory (entrepreneurial culture, economic development, and innovation intensity of the region) are hampering their production function.

Concerning the second configuration with the highest consistency score (TT_2), a more detailed analysis reveals that universities within this group are large and enjoy a 
significant amount of resources. Probably, because of this enough in-house expertise, know-how and capital, they do not need externalising additional support services for TT purposes. Another common feature is how they manage their TT portfolio, which tends to be large, both in terms of breadth (variety of outputs) and depth (amount of the same output). Said differently, these universities are good at the different outputs measured, particularly in IIP and income from R\&D contracts. Some representative universities that belong to this group are UB, UV and US. This is a subgroup of universities that are also well explained by this recipe and that are also good at new venture creation. Specifically, UGR together with two of the largest technical universities in Spain (UPC and UPM) are also obtaining outstanding results in spin-off creation compared to their counterparts.

Lastly, it is worth highlighting two universities (UMA and UM) that despite fitting well within this group (consistency scores $>0.5$ ) seem to experience some troubles when aligning their resources, as TT outcomes lag far behind the ones obtained by the other universities. As observed in TT_1, both universities are located in peripheral areas, with low tradition in knowledge-intensive industries.

\section{Discussion}

In a knowledge-driven setting where different stakeholders demand more transparency in the autonomous governance of public institutions, universities are trying to find an appropriate balance between their three core missions, assuming new roles and responsibilities that could potentially lead to the modernisation of their governance structures and operations. In this context, the study of the ways through which universities align their resources in relation to their missions has become a critical research issue. In the specific case of the third mission, existing research has mainly 
focused on investigating why some universities are more prone than others to produce TT outcomes. While this approach is valid, previous studies have failed to acknowledge the heterogeneity among universities. The one-size-fits all model may hinder differentiation at macro level, but not necessarily at micro level. The novelty of this study lies in recognising this diversity at the institutional level.

Accordingly, our study contributes to the existing literature by acknowledging universities' capacity to leverage competitive advantages from their unique combination of resources (as a result of their heterogeneity). Under a RBV perspective, and considering that universities may produce different mixes of TT outputs (based on their specific features and strategic orientation), this study provides new evidence on how universities perform in TT activities. Our findings confirm that TT portfolios might differ in breadth (variety of outcomes) and in depth among universities. Following the recent debates on the importance of managing resources efficiently, this study can be helpful for university managers to select appropriate benchmarks (i.e., market niche in which to position) and how to reach it (i.e., how resources should be combined) to successfully compete in the HE system. We believe this approach constitutes a unique persepctive to the existing literature. To perform this analysis we employed QCA, an innovative methodology in the HE sector that allows acknowledging institutional diversity. In order to account for the heterogeneity of the Spanish HE system and properly characterise it, we do not impose any restriction on how factors should be combined to achieve a particular TT profile.

Our work also contributes to expand the literature on regional development and the competitiveness of territories. We have studied resource consumption patterns in a low differentiated HE system (Spain) with low flexibility to leverage organisational resources that might provide a competitive advantage. Even in this case, we have been 
able to identify different patterns, validating our hypothesis that universities create competitive advantage by specialising (combine resources in a specific way to maximise their capabilities in the production of TT outcomes). Specifically, our findings support our initial propositions. First, universities have different TT profiles; therefore, efforts on resource allocation are not equal for all of them. Second, a specific TT profile (outcome) can be obtained through different resource consumption patterns. From a RVB perspective, this indicates that the considered resources are substitutable so they do not constitute a competitive advantage for Spanish universities in TT activities per se.

Our results are also in line with those obtained in previous works. As expected in such a knowledge intensive sector, academic staff and TTO staff are the most relevant resources in TT activities, confirming the results from previous research that highlights the relevance of human resources for universities (e.g. Mansfield and Lee, 1996; Powers and McDougal, 2005; Feng et al., 2012). Financial resources are also key antecedents (as also showed for example by Berbegal-Mirabent et al., 2012), especially in two cases: to compensate for the lack of human resources through outsourcing, and to cover the cost of non-financial resources (patterns in which human resources and/or outsourcing are strongly relevant also rely on strong funding). Beyond the extreme patterns of lack of resources (scarce TTO staff, financial resources and evaluation support) or abundant resources (large budgets, TTO staff and external commercialisation services), we find a number of intermediate configurations. Commercialisation services are found to have a positive effect on TT, but a critical mass of human capital or a large TTO budget can help overcome the absence of such services. In turn, external support services together with TTO staff can compensate low academic staff. Results also reveal that a shortage in financial resources is not an 
impediment for transferring technology if there is a skilled pool of researchers and external commercialisation services available. However, it is important noting that moderate budgets can also yield TT outcomes when other resources are scarce, a consumption pattern especially successful for TT portfolios specialised in a single TT outcome.

From the results reported here, several implications can be drawn, bringing new insights to both university managers and scholars in the field of TT. First, different pathways are envisioned, revealing that Spanish universities use different schemes to provide TT outcomes. These finding reinforce the idea that universities should follow the path that best suits their features and strategic vision. Notwithstanding, different production processes (with also different levels of inputs and outputs) may be related with different levels of efficiency and effectiveness or success. For a given TT portfolio, future research may investigate into the efficiency and effectiveness implications of each resource pattern.

The empirical validation of our propositions also concerns policy makers in the sense that the same policy could be effective and benefit some types of HE institutions but not others (see for example Favero and Rutherford, 2019 for the case of performance funding policies). In the specific case of TT, a government willing to encourage TT activities, should bear in mind that universities would respond to incentives differently, that is, welcoming different resources because they rely on distinct patterns. For example, if a particular government wants to support the creation of spin-offs, some universities would welcome the possibility of hiring more technical staff, while others would respond to fund increases, and others would ask for more flexible schemes to deal with equity issues and IIP. Likewise, for specific types of TT outcomes, some resources may not be so relevant. For example, if governments intend 
to encourage university-industry collaborations through IIP agreements, they should not focus on universities access to external companies able to support them in TT processes, because outsourcing seem not to be relevant for the production of this particular TT result.

\section{Concluding remarks}

Universities are increasingly being called to be active drivers of economic growth and competitiveness (Shattock, 2009). In order to facilitate this role, policy-makers and university managers have launched initiatives and incentive schemes aimed at facilitating the commercialisation of academic research and at increasing the participation of science in resolving societal challenges (Arocena et al., 2018; Audretsch, 2014). Within this role, universities act as both knowledge and technologyproducers but also as results-disseminators. As Harrison and Turok (2017) state, "fortunately, universities have much to offer since knowledge and human capital now constitute crucial drivers of prosperity, inclusion and territorial development" (p. 978). Thus, by accepting this role, universities, together with industry and government, are becoming part of a system that supports innovation and economic progress (Etzkowitz and Leydesdorff, 2000).

Universities' third mission is aimed at responding to these calls. TT activities are primarily designed to support regional engagement and regional economic growth more generally, while, at the same time, bring universities a complementary income stream (through the valorisation and commercialisation of knowledge in the marketplace).

Another generalised trend in the HE sector is the increasing competition among universities, both at international and national levels. Although the level of competition in the Spanish HE system is low-when compared for example to the Anglo-Saxon 
systems - the HE sector has become increasingly competitive and market-like also in Spain. Most of the Spanish public universities have little managerial flexibility to compete for some basic resources such as the best quality researchers and students (de la Torre et al., 2017b), hardly pursue development funds (fundraising) and do not have to compete for their core funding (block grant) — see Perez-Esparrells and de la Torre (2016). However, with the resources they have, they do compete for research funds from competitive calls and seek to advance their reputation for excellence through scaling positions in the global rankings. TT is an example of a domain in which universities compete for funding and possibilities, and consequently, in this field our theoretical propositions are empirically demonstrated: (i) not all Spanish universities allocate their efforts towards producing the same type of TT outcomes (TT profiles); and (ii) Spanish universities reach specific TT outcomes through different resource consumption patterns.

By focusing on the case of Spain, we believe this study complements the results of recent contributions that prove that the institutional diversity of the HE system goes beyond the traditionally recognised diversity sources: legal status, size and subject mix (de la Torre et al., 2018). Despite the homogeneous conception of the Spanish HE system at the macro level (the same duties are assigned to all universities - see Casani et al., 2014), we have shown the differentiation at institutional level in terms of patterns of consumption of resources (inputs) and TT portfolios (outputs). Yet, we are aware that, unlike previous $\mathrm{RBV}$ research, our empirical approach focusses on tangible resources for TT activities - not on the external and internal, intangible capabilities and resources behind the consumption patterns and TT portfolios (e.g. quality and expertise of the staff, institutional culture, socioeconomic level of the university region). Also, different territories may display different patterns. These are interesting routes for future 
research. Taking into account additional types of resources could shed light in the competitive advantages and performance levels of Spanish universities; and testing the models in other countries would show interesting results complementary to those for the Spanish case.

\section{References}

Abankina, I., Aleskerov, F., Belousova, V., Gokhberg, L., Kiselgof, S., Petrushchenko, V., Shvydun, S. and Zinkovsky, K. (2016), "From equality to diversity: Classifying Russian universities in a performance oriented system", Technological Forecasting and Social Change, Vol. 103, pp. 228-239.

Agasisti, T., Barra, C. and Zotti, R. (2016), "Evaluating the efficiency of Italian public universities (2008-2011) in presence of (unobserved) heterogeneity", SocioEconomic Planning Sciences, Vol. 55, pp. 47-58.

Agasisti, T. and Johnes, G. (2015), "Efficiency, costs, rankings and heterogeneity: The case of US higher education”, Studies in Higher Education, Vol. 40 No. 1, pp. $60-82$.

Álvarez-Coque, J.M.G., Mas-Verdú, F. and Roig-Tierno, N. (2017), “Technological innovation versus non-technological innovation: Different conditions in different regional contexts?", Quality \& Quantity, Vol. 51 No. 5, pp. 1955-1967.

Amit, R. and Schoemaker, P.J.H. (1993), "Strategic assets and organizational rent", Strategic Management Journal, Vol. 14 No. 1, pp. 33-46.

Antonelli, C. (2008), "The new economics of the university: A knowledge governance approach", Journal of Technology Transfer, Vol. 1 No. 33, pp. 1-22.

Arocena R., Göransson B. and Sutz J. (2018), "Academic roles, evaluation and development”, in Arocena R., Göransson B. and Sutz, J. (Eds.), Developmental 
universities in inclusive innovation systems, Palgrave Macmillan, Cham, pp. $181-224$.

Arora, A. Fosfuri, A. and Gambardella, A. (2001), Markets for technology: The economics of innovation and corporate strategy, MIT Press, Cambridge.

Audretsch, D.B. (2014), "From the entrepreneurial university to the university for the entrepreneurial society", Journal of Technology Transfer, Vol. 39 No. 3, pp. $313-321$.

Autio, E., Hameri, A.P. and Vuola, O. (2004), "A framework of industrial knowledge spillovers in big-science centers", Research Policy, Vol. 33 No. 1, pp. 107-126.

Barney, J.B. (1991), "Firm resources and sustained competitive advantage", Journal of Management, Vol. 17 No. 1, pp. 99-120.

Bartelse, J. and Vught, F. (2007), "Institutional profiles: Towards a typology of higher education institutions in Europe", IAU Horizons, Vol. 13 No. 2/3, pp. 9-11.

Berbegal-Mirabent, J., Gil-Doménech, D. and De la Torre, R. (2019), "Dealing with heterogeneity: An analysis of Spanish universities", Tec Empresarial, Vol. 13 No. 3, pp. 58-77.

Berbegal-Mirabent, J., Lafuente, E. and Solé, F. (2013), “The pursuit of knowledge transfer activities: An efficiency analysis of Spanish universities", Journal of Business Research, Vol. 66 No. 10, pp. 2051-2059.

Berbegal-Mirabent, J., Ribeiro-Soriano, D.E. and Sánchez-García, J.L. (2015), “Can a magic recipe foster university spin-off creation?”, Journal of Business Research, Vol. 68 No. 11, pp. 2272-2278.

Berbegal-Mirabent, J., Sabaté, F. and Cañabate, A. (2012), "Brokering knowledge from universities to the marketplace: The role of knowledge transfer offices", Management Decision, Vol. 50 No. 7, pp. 1285-1307. 
Bobe, B.J. and Kober, R. (2015), "Measuring organisational capabilities in the higher education sector", Education + Training, Vol. 57 No. 3, pp. 322-342.

Boliver, V. (2015), “Are there distinctive clusters of higher and lower status universities in the UK?", Oxford Review of Education, Vol. 41 No. 5, pp. 608-627.

Bonaccorsi, A. and Daraio, C. (2009), "Characterizing the European university system: A preliminary classification using census microdata", Science and Public Policy, Vol. 36 No. 10, pp. 763-775.

Cabanelas, P., Cabanelas-Omil, J., Lampón, J.F. and Somorrostro, P. (2017). The governance of regional research networks: lessons from Spain. Regional Studies, Vol. 51 No. 7, pp. 1008-1019.

Caldera, A. and Debande, O. (2010), "Performance of Spanish universities in technology transfer: An empirical analysis”, Research Policy, Vol. 39 No. 9, pp. $1160-1173$.

Callon, M. and Muniesa, F. (2005), "Peripheral vision: Economic markets as calculative collective devices", Organization Studies, Vol. 26, pp. 1229-1250.

Cartaxo, R.M. and Godinho, M.M. (2017), "How institutional nature and available resources determine the performance of technology transfer offices", Industry and Innovation, Vol. 24 No. 7, pp. 713-734.

Casani, F., De Filippo, D., García-Zorita, C. and Sanz-Casado, E. (2014), “Public versus private universities: Assessment of research performance: case study of the Spanish university system", Research Evaluation, Vol. 23 No. 1, pp. 48-61.

Castillo, F., Gilless, J.K., Heiman, A. and Zilberman, D. (2018), “Time of adoption and intensity of technology transfer: an institutional analysis of offices of technology transfer in the United States", Journal of Technology Transfer, Vol. 43 No. 1, pp. $120-138$. 
Cesaroni, F. and Piccaluga, A. (2016), “The activities of university knowledge transfer offices: Towards the third mission in Italy", Journal of Technology Transfer, Vol. 41 No. 4, pp. 753-777.

Christmann, P. (2000), “Effects of 'best practices' of environmental management on cost advantage: the role of complementary assets", Academy of Management Journal, Vol. 43 No. 4, pp. 663-680.

Daraio, C., Bonaccorsi, A., Geuna, A., Lepori, B., Bach, L., Bogetoft, P., et al. (2011), "The European university landscape: A micro characterization based on evidence from the Aquameth project”, Research Policy, Vol. 40 No. 1, pp. 148164.

De Coster, R. and Butler, C. (2005), “Assessment of proposals for new technology ventures in the UK: Characteristics of university spin-off companies", Technovation, Vol. 25 No. 5, pp. 535-543.

de la Torre, E.M., Agasisti, T. and Perez-Esparrells, C. (2017a), "The relevance of knowledge transfer for universities' efficiency scores: An empirical approximation on the Spanish public higher education system", Research Evaluation, Vol. 26 No. 3, pp. 211-229.

de la Torre, E.M., Gómez-Sancho, J.M. and Perez-Esparrells, C. (2017b), “Comparing university performance by legal status: a Malmquist-type index approach for the case of the Spanish Higher Education System", Tertiary Education and Management, Vol. 23 No. 3, pp. 206-221.

de la Torre, E.M., Casani, F. and Sagarra, M. (2018), "Defining typologies of universities through a DEA-MDS analysis: An institutional characterisation for formative evaluation purposes", Research Evaluation, Vol. 27 No. 4, pp. 388403. 
de la Torre, E.M., Rossi, F. and Sagarra, M. (2019), "Who benefits from HEIs engagement? An analysis of priority stakeholders and activity profiles of HEIs in the United Kingdom”, Studies in Higher Education, Vol. 44 No. 12, pp. 2163-2182.

De la Torre, R., Lusa, A. and Mateo, M. (2016), "A MILP model for the long term academic staff size and composition planning in public universities", Omega, Vol. 63, pp. 1-11.

D'Este, P. and Perkmann, M. (2011), “Why do academics engage with industry? The entrepreneurial university and individual motivations", Journal of Technology Transfer, Vol. 36 No. 3, 316-339.

Ensign, P.C. (2004), “A resource-based view of interrelationships among organizational groups in the diversified firm", Strategic Change, Vol. 13 No. 3, pp. 125-137.

Etzkowitz, H. (2004), “The evolution of the entrepreneurial university”, International Journal of Technology and Globalization, Vol. 1 No. 1, pp. 64-77.

Etzkowitz, H. (1998), “The norms of entrepreneurial science: Cognitive effects of the new university-industry linkages", Research Policy, Vol. 27 No. 8, pp. 823-833.

Etzkowitz, H. and Leydesdorff, L. (2000), “The dynamics of innovation: From National Systems and "Mode 2" to a Triple Helix of university-industry-government relations", Research Policy, Vol. 29 No. 2, pp. 109-123.

Etzkowitz, H., Webster, A., Gebhardt, C. and Cantisano Terra, B.R. (2000), “The future of the university and the university of the future: evolution of ivory tower to entrepreneurial paradigm”, Research Policy, Vol. 29 No. 2, pp. 313-330.

European Indicators and Ranking Methodology for University Third Mission - E3M (2012), "Fostering and Measuring Third Mission in Higher Education 
Institutions". Green Paper. <http://www.e3mproject.eu/docs/Green\%20paperp.pdf> accessed 25 May 2020.

Favero, N. and Rutherford, A. (2019), "Will the tide lift all boats? Examining the equity effects of performance funding policies in U.S. higher education", Research in Higher Education, Vol. 61 No. 1, pp. 1-25.

Feng, H.I., Chen, C.S., Wang, C.H. and Chiang, H.C. (2012), "The role of intellectual capital and university technology transfer offices in university-based technology transfer", The Service Industries Journal, Vol. 32 No. 6, pp. 899-917.

Fiss, P.C. (2011), "Building better causal theories: A fuzzy set approach to typologies in organization research", Academy of Management Journal, Vol. 54 No. 2, pp. $393-420$.

Foss, N.J., Klein, P., Kor, Y. and Mahoney, J. (2008), “Entrepreneurship, subjectivism, and the resource-based view", Strategic Entrepreneurship Journal, Vol. 2 No. 1, pp. 73-94.

Gibbert, M. (2006), “Generalizing about uniqueness: an essay on an apparent paradox in the resource-based view", Journal of Management Inquiry, Vol. 15 No. 2, pp. $124-134$.

Grimpe, C. and Hussinger, K. (2013), "Formal and informal knowledge and technology transfer from academia to industry: Complementarity effects and innovation performance", Industry and Innovation, Vol. 20 No. 8, pp. 683-700.

Guerrero, M. and Urbano, D. (2012), "The development of an entrepreneurial university", Journal of Technology Transfer, Vol. 37 No. 1, pp. 43-74.

Gunasekara, C. (2006), "Reframing the role of universities in the development of regional innovation systems", Journal of Technology Transfer, Vol. 31 No. 1, pp. 101-113. 
Harrison, J. and Turok, I. (2017), "Universities, knowledge and regional development", Regional Studies, Vol. 51 No. 7, pp. 977-981.

Hladchenko, M. and Pinheiro, R. (2019), "Implementing the triple helix model: Meansends decoupling at the state level?", Minerva, Vol. 57 No. 1, pp. 1-22.

Howells, J., Ramlogan, R. and Cheng, S.L. (2008), The role, context and typology of universities and higher education institutions in innovation systems: A UK perspective. Discussion Papers and Project Reports, Impact of Higher Education Institutions on Regional Economics: A Joint Research Initiative, available at: https://ewds.strath.ac.uk/Portals/8/typology.doc. Accessed 06 August 2019.

Johnes, J. (2006), "Data envelopment analysis and its application to the measurement of efficiency in higher education", Economics of Education Review, Vol. 25 No. 3, pp. 273-288.

Johnes, G. and Johnes, J. (2009), 'Higher education institutions' costs and efficiency: Taking the decomposition a further step", Economics of Education Review, Vol. 28 No. 1, pp. 107-113.

Kitawa, F. (2010), "Pooling resources for excellence and relevance: An evolution of universities as multi-scalar network organisations”, Minerva, Vol. 48 No. 2, pp. $169-187$.

Kraaijenbrink, J., Spender, J.C. and Groen, A.J. (2010), “The resource-based view: A review and assessment of its critiques", Journal of Management, Vol. 36 No. 1, pp. 349-372.

Lafuente, E. and Berbegal-Mirabent, J. (2019), "Assessing the productivity of technology transfer offices: an analysis of the relevance of aspiration performance and portfolio complexity", Journal of Technology Transfer, Vol. 44 No. 3, pp. 778-801. 
Lampel, J. and Shamsie, J. (2003), "Capabilities in motion: new organizational forms and the reshaping of the Hollywood movie industry", The Journal of Management Studies, Vol. 40 No. 8, pp. 2189-2210.

Landry, R., Amara, N. and Ouimet, M. (2007), "Determinants of knowledge transfer: Evidence from Canadian university researchers in natural sciences and engineering”, Journal of Technology Transfer, Vol. 32 No. 6, pp. 561-592.

Larty, J., Jack, S. and Lockett, N. (2017), "Building regions: a resource-based view of a policy-led knowledge exchange network", Regional Studies, Vol. 51 No. 7, pp. 994-1007.

Lazzarotti, V., Manzini, R., Nosella, A. and Pellegrini, L. (2016), "Collaborations with scientific partners: The mediating role of the social context in fostering innovation performance", Creativity and Innovation Management, Vol. 25 No. 1, pp. 142-156.

Lichtenthaler, U. and Ernst, H. (2012), "Intermediary services in the markets for technology: Organizational antecedents and performance consequences", Organization Studies, Vol. 29 No. 7, pp. 1003-1035.

Maduro, S., Fernandes, P.P. and Alves, A. (2018), "Management design as a strategic lever to add value to corporate reputation competitiveness in higher education institutions", Competitiveness Review: An International Business Journal, Vol. 28 No. 1 , pp. $75-97$.

Maietta, O.W. (2015), "Determinants of university-firm R\&D collaboration and its impact on innovation: A perspective from a low-tech industry", Research Policy, Vol. 44 No. 7, pp. 1341-1359. 
Mansfield, E. and Lee, J. (1996), “The modern university: contributor to industrial innovation and recipient of industrial R\&D support", Research Policy, Vol. 25, pp. 1047-1058.

McCormick, A.C. and Zhao, C.M. (2005), "Rethinking and reframing the Carnegie classification", Change: The Magazine of Higher Learning, Vol. 37 No. 5, pp. $51-57$

Meyer, A.D., Tsui, A.S. and Hinings, C.R. (1993), "Configurational approaches to organizational analysis", Academy of Management Journal, Vol. 36 No. 6, pp. $1175-1195$.

Molloy, J.C., Chadwick, C., Ployhart, R.E. and Golden, S.J. (2011), "Making intangibles 'tangible' in tests of resource-based theory: a multidisciplinary construct validation approach", Journal of Management, Vol. 37 No. 5, pp. $1496-1518$.

Muscio, A. (2010), "What drives the university use of technology transfer offices? Evidence from Italy”, Journal of Technology Transfer, Vol. 35 No. 2, pp. 181202.

Newbert, S.L. (2007), "Empirical research on the resource-based view of the firm: an assessment and suggestions for future research", Strategic Management Journal, Vol. 28 No. 2, pp. 121-146.

Newbert, S.L. (2008), "Value, rareness, competitive advantage, and performance: a conceptual level empirical investigation of the resource-based view of the firm", Strategic Management Journal, Vol. 29 No. 7, pp. 745-768.

Niederl, A., Bonaccorsi, A., Lepori, B., Brandt, T., De Filippo, D., Schmoch, U., et al. (2014), "Mapping the European higher education landscape: New insights from the EUMIDA project", in Bonaccorsi, A. (Ed.), Knowledge, diversity and 
performance in European higher education. A changing landscape, Edwar Elgar, Chektelham and Northampton, pp. 13-46.

O'Shea, R., Chugh, H. and Allen, T.J. (2008), “Determinants and consequences of university spin-off activity: A conceptual framework", Journal of Technology Transfer, Vol. 33 No. 6, pp. 653-666.

Parker, R. and Hine, D. (2014), “The role of knowledge intermediaries in developing firm learning capabilities", European Planning Studies, Vol. 22 No. 5, pp. 1048-1061.

Penrose, E.T. (1959), The Theory of the Growth of the Firm, Wiley, New York.

Perez-Esparrells, C. and de la Torre, E.M. (2016), "La filantropía y el fundraising en las universidades públicas españolas como estrategia de sostenibilidad futura: ¿algo está cambiando?", Investigaciones de Economía de la Educación, No 11, pp. $173-186$.

Perkmann, M., Tartari, V., McKelvey, M., Autio, E., Broström, A., D’Este, P., et al. (2013), "Academic engagement and commercialisation: A review of the literature on university-industry relations", Research Policy, Vol. 42 No. 2, pp. 423-442.

Powers J.B. (2004), "R\&D funding sources and university technology transfer: What is stimulating universities to be more entrepreneurial?", Research in Higher Education, Vol. 45 No. 1, pp. 1-23.

Powers, J.B. and McDougall, P.P. (2005), "University start-up formation and technology licensing with firms that go public: A resource based view of academic entrepreneurship", Journal of Business Venturing, Vol. 20 No. 3, pp. $291-311$. 
Prahalad, C.K. and Hamel, G. (1990), "The core competence of the corporation", Harvard Business Review, Vol. 68 No. 3, pp. 79-91.

Pugh, R. (2017), “Universities and economic development in lagging regions: 'Triple helix' policy in Wales", Regional Studies, Vol. 51 No. 7, pp. 982-993.

Ragin, C.C. (2013), The comparative method: Moving beyond qualitative and quantitative strategies, University of California Press, California.

Ragin, C.C. (2008), Redesigning social inquiry: Fuzzy sets and beyond, University of Chicago Press, Chicago.

Ragin, C.C. and Fiss, P.C. (2008), "Net effects analysis versus configurational analysis: An empirical demonstration", in Ragin, C.C. (Ed.), Redesigning social inquiry: Fuzzy sets and beyond, University of Chicago Press, Chicago, pp. 190-212.

Rihoux, B. and Ragin, C.C. (2009), Configurational comparative methods: Qualitative comparative analysis (QCA) and related techniques, Sage, Singapore.

Rouse, M.J. and Daellenbach, U.S. (2002), "More thinking on research methods for the resource-based perspective", Strategic Management Journal, Vol. 23 No. 10, pp. 963-967.

Rumelt R.P. (1997), "Towards a strategic theory of the firm", in Foss, N.J. (Ed.), Resources, firms, and strategies: A reader in the resource-based perspective, Oxford University Press, New York, pp. 131-145.

Sá, C., Kretz, A. and Sigurdson, K. (2013), “Techno-nationalism and the construction of university technology transfer", Minerva, Vol. 51 No. 4, pp. 443-464.

Sánchez-Barrioluengo, M. (2014), “Articulating the 'three-missions' in Spanish universities", Research Policy, Vol. 43, pp. 1760-1773. 
Schneider, C.Q. and Wagemann, C. (2012), Set-theoretic methods for the social sciences: A guide to qualitative comparative analysis, Cambridge University Press, Cambridge.

Secundo, G., De Beer, C. and Passiante, G. (2016), "Measuring university technology transfer efficiency: A maturity level approach", Measuring Business Excellence, Vol. 20 No. 3, pp. 42-54.

Selznick, P. (1957), Leadership in Administration, Harper and Row, New York.

Shattock, M. (2009), Entrepreneurialism in universities and the knowledge economy, Society for Research into Higher Education and Open University Press, Maidenhead.

Stensaker, B. and Benner, M. (2013), "Doomed to be entrepreneurial: Institutional transformation or institutional lock-ins of 'new' universities?”, Minerva, Vol. 51 No. 4, pp. 399-416.

Stonkiene, M., Matkeviciene, R. and Vaiginiene, E. (2016), "Evaluation of the national higher education system's competitiveness: Theoretical model”, Competitiveness Review: An International Business Journal, Vol. 26 No. 2, pp. $116-131$.

Thursby, J.G. and Thursby, M.C. (2002), "Who is selling the ivory tower? Sources of growth in university licensing", Management Science, Vol. 48 No. 1, pp. 90104.

Uyarra, E. (2010), "Conceptualizing the regional roles of universities, implications and contradictions”, European Planning Studies, Vol. 18 No. 8, pp. 1227-1246.

Vallance, P. (2016), "Universities, public research, and evolutionary economic geography”, Economic Geography, Vol. 92 No. 4, pp. 355-377. 
Vis, B. (2012), "The comparative advantages of fsQCA and regression analysis for moderately large-N analyses", Sociological Methods \& Research, Vol. 41 No. 1, pp. 168-198.

Wernerfelt, B. (1984), “A resource-based view of the firm”, Strategic Management Journal, Vol. 5 No. 2, pp. 171-180.

Woodside, A.G. (2016), “The good practices manifesto: Overcoming bad practices pervasive in current research in business", Journal of Business Research, Vol. 69 No. 2 pp. 365-381.

Wu, P.L., Yeh, S.S. and Woodside, A.G. (2014), "Applying complexity theory to deepen service dominant logic: Configural analysis of customer experience-andoutcome assessments of professional services for personal transformations", Journal of Business Research, Vol. 67 No. 8, pp. 1647-1670. 


\section{List of Tables}

Table 1. Descriptive statistics of outcomes and antecedent conditions (resources).

\begin{tabular}{|c|c|c|c|c|c|c|c|}
\hline \multicolumn{3}{|l|}{ Variables } & Mean & Std. dev. & Min. & Max. & Year \\
\hline \multirow{3}{*}{ Outcomes } & \multicolumn{2}{|c|}{$\begin{array}{l}\text { Intellectual or industrial property } \\
\text { (IIP) agreements }\end{array}$} & 29.43 & 26.84 & 2.0 & 126.0 & 2015 \\
\hline & \multicolumn{2}{|c|}{$\begin{array}{l}\text { Spin-offs established in the last five } \\
\text { years }\end{array}$} & 12.45 & 17.02 & 0.0 & 97.0 & 2015 \\
\hline & \multicolumn{2}{|c|}{$\mathrm{TT}_{\text {income }} \mathrm{a}^{\mathrm{a}}$} & $7,343.71$ & $7,139.02$ & 406.81 & $30,212.97$ & 2015 \\
\hline \multirow{5}{*}{$\begin{array}{l}\text { Antecedent } \\
\text { conditions } \\
\text { (resources) }\end{array}$} & \multirow{2}{*}{$\begin{array}{l}\text { Human } \\
\text { resources }\end{array}$} & Faculty members (FTE) & 1636.86 & 961.96 & 348.33 & 4329.91 & 2013 \\
\hline & & TTO staff (FTE) & 14.04 & 15.05 & 3.00 & 88.00 & 2013 \\
\hline & $\begin{array}{l}\text { Financial } \\
\text { resources }\end{array}$ & TTO budget ${ }^{\mathrm{a}}$ & 541.03 & 591.65 & 4.50 & 2787.00 & 2013 \\
\hline & \multirow{2}{*}{$\begin{array}{l}\text { Support } \\
\text { services }\end{array}$} & $\begin{array}{l}\text { Invention disclosure } \\
\text { evaluation }\end{array}$ & 0.45 & 0.50 & 0.00 & 1.00 & 2013 \\
\hline & & Commercialisation & 0.38 & 0.49 & 0.00 & 1.00 & 2013 \\
\hline
\end{tabular}

${ }^{a}$ Units in thousand $€$.

FTE: Full time equivalent.

Table 2. Calibration values.

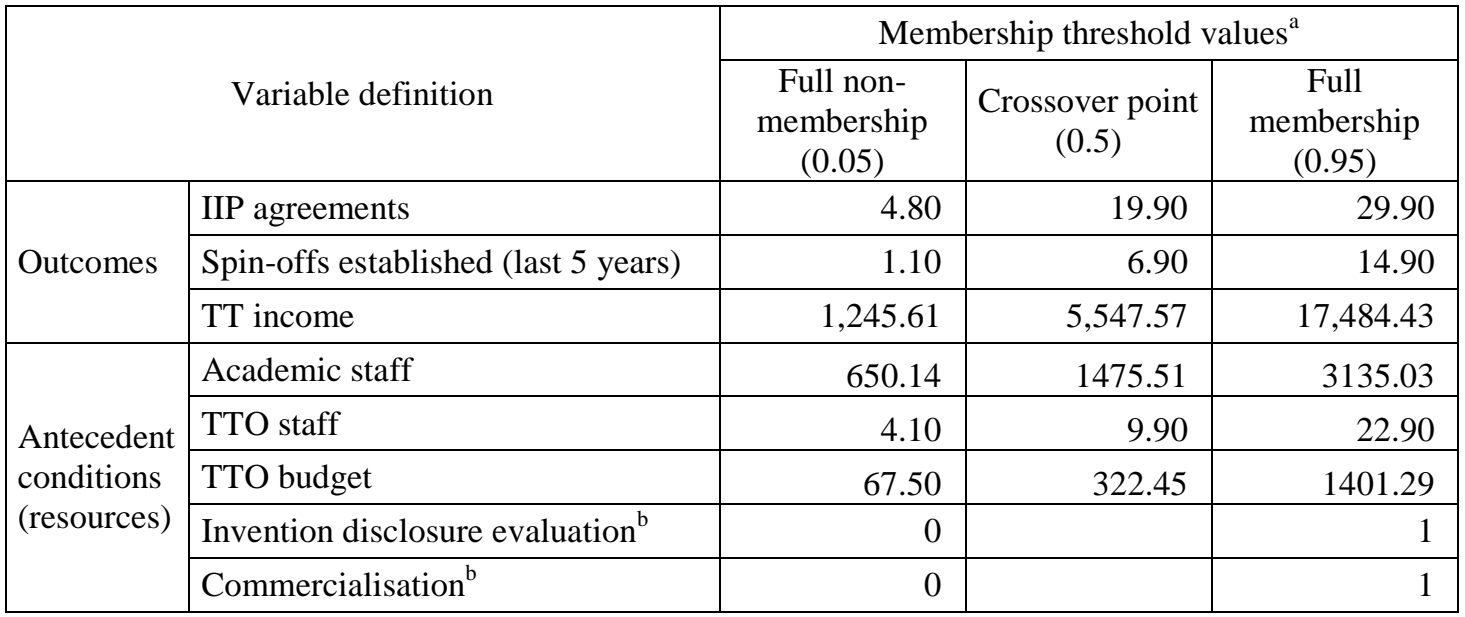

${ }^{a}$ Observations falling in the percentile-90 to represent full set membership. Percentile-10 is the threshold value to indicate full non-membership. The crossover point is defined by the median. Minor modifications are then made in order to better adjust the calibration to the reality they represent.

${ }^{\mathrm{b}}$ Expressed in crisp-set terms. 
Table 3. Sufficient configurations of antecedent conditions for the different outcomes.

\begin{tabular}{|c|c|c|c|c|c|c|}
\hline $\begin{array}{l}\text { Model 1: } \\
\text { IIP agreements }\end{array}$ & IIP_1 & IIP_2 & \multicolumn{2}{|c|}{ IIP_3 } & IIP_4 & IIP_5 \\
\hline Academic staff & $\bullet$ & $\bullet$ & & & $\bullet$ & $\bullet$ \\
\hline TTO staff & & 0 & \multicolumn{2}{|c|}{$\bullet$} & $\bullet$ & $\bullet$ \\
\hline TTO budget & O & O & \multicolumn{2}{|c|}{$\bullet$} & & $\bullet$ \\
\hline Invention disclosure evaluation & O & \multirow[b]{2}{*}{ O } & \multicolumn{2}{|c|}{$\mathrm{O}$} & 0 & 0 \\
\hline Commercialisation & O & & \multicolumn{2}{|c|}{$\mathrm{O}$} & O & \\
\hline Raw coverage & 0.1654 & 0.2258 & \multicolumn{2}{|c|}{0.1082} & 0.2596 & 0.2920 \\
\hline Unique coverage & 0.0500 & 0.1104 & \multicolumn{2}{|c|}{0.0572} & 0.0104 & 0 \\
\hline Consistency & 0.8973 & 0.9347 & \multicolumn{2}{|c|}{1} & 0.9648 & 0.9774 \\
\hline \multicolumn{7}{|c|}{ Solution coverage: 0.5282 . Solution consistency: 0.9406} \\
\hline $\begin{array}{l}\text { Model 2: } \\
\text { Spin-offs established in the last five } \\
\text { years }\end{array}$ & S_1 & S_2 & S_3 & S_4 & S_5 & S_6 \\
\hline Academic staff & $\bullet$ & $\bullet$ & O & $\bullet$ & $\mathrm{O}$ & $\bullet$ \\
\hline TTO staff & $\bullet$ & $\bullet$ & O & O & $\bullet$ & $\bullet$ \\
\hline TTO budget & O & & $\bullet$ & O & O & $\bullet$ \\
\hline Invention disclosure evaluation & & $\bullet$ & O & O & $\bullet$ & O \\
\hline Commercialisation & O & O & O & $\bullet$ & $\bullet$ & $\bullet$ \\
\hline Raw coverage & 0.2109 & 0.1243 & 0.1634 & 0.0903 & 0.0656 & 0.0526 \\
\hline Unique coverage & 0.0410 & 0.0135 & 0.1043 & 0.0410 & 0.0163 & 0.0526 \\
\hline Consistency & 0.8451 & 0.8900 & 0.8540 & 0.8050 & 0.8598 & 1 \\
\hline Solution coverage: 0.4879 . Solution cons & tency: 0.8 & 424 & & & & \\
\hline $\begin{array}{l}\text { Model 3: } \\
\text { RD income }\end{array}$ & RD_1 & RD_2 & RD_3 & RD_4 & RD_5 & RD_6 \\
\hline Academic staff & $\bullet$ & O & $\bullet$ & $\bullet$ & $\bullet$ & $\bullet$ \\
\hline TTO staff & $\bullet$ & $\bullet$ & $\bullet$ & $\mathrm{O}$ & $\bullet$ & $\bullet$ \\
\hline TTO budget & 0 & & $\bullet$ & O & & $\bullet$ \\
\hline Invention disclosure evaluation & & $\bullet$ & & $\mathrm{O}$ & $\bullet$ & $\bullet$ \\
\hline Commercialisation & $\mathrm{O}$ & $\bullet$ & $\bullet$ & $\bullet$ & $\mathrm{O}$ & \\
\hline Raw coverage & 0.2614 & 0.1017 & 0.2164 & 0.0427 & 0.1473 & 0.2372 \\
\hline Unique coverage & 0.1259 & 0.0506 & 0.0495 & 0.0287 & 0 & 0 \\
\hline Consistency & 0.8675 & 0.8786 & 0.9772 & 0.8941 & 0.8733 & 0.9526 \\
\hline Solution coverage: 0.5689 . Solution cons & tency: 0.8 & 901 & & & & \\
\hline $\begin{array}{l}\text { Model 4: } \\
\text { Technology Transfer (IPP agreements } \\
\text { OR spin-offs OR TT income) }\end{array}$ & TT_1 & TT_2 & TT_3 & TT_4 & TT_5 & TT_6 \\
\hline Academic staff & & $\bullet$ & & $\mathrm{O}$ & $\bullet$ & $\mathrm{O}$ \\
\hline TTO staff & $\mathrm{O}$ & $\bullet$ & $\bullet$ & & $\mathrm{O}$ & $\bullet$ \\
\hline TTO budget & O & & $\bullet$ & $\bullet$ & O & \\
\hline Invention disclosure evaluation & O & & & O & & $\bullet$ \\
\hline Commercialisation & & 0 & $\bullet$ & O & $\bullet$ & $\bullet$ \\
\hline Raw coverage & 0.2520 & 0.3064 & 0.2018 & 0.1614 & 0.0948 & 0.0718 \\
\hline Unique coverage & 0.1028 & 0.1938 & 0.1234 & 0.0387 & 0.0213 & 0.0073 \\
\hline Consistency & 0.8051 & 0.9799 & 1 & 0.8670 & 0.8344 & 1 \\
\hline
\end{tabular}

Frequency threshold $=1$.

Consistency threshold $=0.8852$ (Model IIP),$=0.8022$ (Model Spin-offs) $=0.8358$ (Models RD income $)=0.8050($ Model TT $)$. 
Table 4. Cases with greater than 0.5 membership in the configurations of model TT.

\begin{tabular}{|c|l|}
\hline Model & \multicolumn{1}{|c|}{ Cases } \\
\hline TT_1 & $\begin{array}{l}\text { USAL }(0.95,0.98), \text { UNIOVI }(0.92,0.53), \text { UVIGO }(0.87,0.87), \text { ULL }(0.82,0.12), \text { UCO } \\
(0.73,0.87), \text { UIB }(0.67,0.39), \text { UPO }(0.65,0.51), \text { UAM }(0.56,0.8)\end{array}$ \\
\hline TT_2 & $\begin{array}{l}\text { UB }(0.95,1), \text { UV }(0.91,1), \text { UPC }(0.74,1), \text { UGR }(0.72,1), \text { US }(0.67,0.99), \text { UMA }(0.63,0.6), \\
\text { UPM }(0.62,1), \text { UM }(0.6,0.51), \text { UVA }(0.58,0.99), \text { UCM }(0.56,1), \text { UA }(0.51,1)\end{array}$ \\
\hline TT_3 & $\begin{array}{l}\text { UC3M }(0.99,0.99), \text { UNIZAR }(0.89,1), \text { UPV }(0.82,1), \text { USC }(0.77,1), \text { EHU }(0.62,1), \\
\text { UNICAN }(0.59,0.85), \text { UDG }(0.57,0.58)\end{array}$ \\
\hline TT_4 & URV $(0.77,0.89)$, URJC $(0.7,0.51)$, UMH $(0.68,1)$, UJI $(0.64,0.12)$ \\
\hline TT_5 & UAB $(0.73,1)$, UNIOVI $(0.6,0.53)$, UCLM $(0.59,0.12)$ \\
\hline TT_6 & UNICAN $(0.62,0.85)$, UDC $(0.56,0.93)$ \\
\hline
\end{tabular}

Note: The first number in the parenthesis indicates the degree of membership to the configuration while the second one stands for the level of output (expressed in fuzzy terms). 
Appendix 1. List of universities included in the sample.

\begin{tabular}{|c|c|}
\hline Coding & University \\
\hline EHU & Universidad del País Vasco \\
\hline UA & Universidad de Alicante \\
\hline $\mathrm{UAB}$ & Universitat Autònoma de Barcelona \\
\hline UAH & Universidad de Alcalá \\
\hline UAL & Universidad de Almería \\
\hline UAM & Universidad Autónoma de Madrid \\
\hline UB & Universitat de Barcelona \\
\hline UBU & Universidad de Burgos \\
\hline UC3M & Universidad Carlos III de Madrid \\
\hline UCLM & Universidad de Castilla - La Mancha \\
\hline $\mathrm{UCM}$ & Universidad Complutense de Madrid \\
\hline $\mathrm{UCO}$ & Universidad de Córdoba \\
\hline UDC & Universidade da Coruña \\
\hline UDG & Universitat de Girona \\
\hline UDL & Universitat de Lleida \\
\hline UGR & Universidad de Granada \\
\hline UIB & Universitat de les Illes Balears \\
\hline UJAEN & Universidad de Jaén \\
\hline UJI & Universitat Jaume I de Castelló \\
\hline ULL & Universidad de La Laguna \\
\hline ULPGC & Universidad de Las Palmas de Gran Canaria \\
\hline $\mathrm{UM}$ & Universidad de Murcia \\
\hline UMA & Universidad de Málaga \\
\hline $\mathrm{UMH}$ & Universidad Miguel Hernández de Elche \\
\hline UNICAN & Universidad de Cantabria \\
\hline UNIOVI & Universidad de Oviedo \\
\hline UNIRIOJA & Universidad de La Rioja \\
\hline UNIZAR & Universidad de Zaragoza \\
\hline UPC & Universitat Politècnica de Catalunya \\
\hline UPM & Universidad Politécnica de Madrid \\
\hline UPO & Universidad Pablo Olavide de Sevilla \\
\hline UPV & Universitat Politècnica de València \\
\hline URJC & Universidad Rey Juan Carlos \\
\hline URV & Universitat Rovira i Virgili \\
\hline US & Universidad de Sevilla \\
\hline USAL & Universidad de Salamanca \\
\hline USC & Universidade de Santiago de Compostela \\
\hline $\mathrm{UV}$ & Universitat de València \\
\hline UVA & Universidad de Valladolid \\
\hline UVIGO & Universidade de Vigo \\
\hline
\end{tabular}

